\title{
26 Research Square \\ Potential of Rice (Oryza Sativa L.) Cultivars to Mitigate Methane Emissions from Irrigated Systems in Latin America and the Caribbean
}

Paul Abayomi Sobowale SOREMI ( $\sim$ soremipas@funaab.edu.ng )

Federal University of Agriculture

Ngonidzashe Chirinda

Agricultural Innovations and Technology Transfer Centre (AITTC), Mohammed VI Polytechnic University (UM6P)

\section{Eduardo Graterol}

Latin American Fund for Irrigated Rice (FLAR), International Center for Tropical Agriculture

Maria F. Alvarez

International Center for Tropical Agriculture (CIAT)

\section{Research Article}

Keywords: Climate change mitigation, Sustainable rice production, Rice cultivars, Methane emissions

Posted Date: March 1st, 2022

DOI: https://doi.org/10.21203/rs.3.rs-1351381/v1

License: (9) This work is licensed under a Creative Commons Attribution 4.0 International License. Read Full License 


\section{Abstract}

Irrigated rice, represents a methane $\left(\mathrm{CH}_{4}\right)$ emissions source. In rice fields, the dominance of plantmediated transportation of $\mathrm{CH}_{4}$ from submerged soils to the atmosphere raises the possibility of varietal differences in $\mathrm{CH}_{4}$ emissions. Previous findings remain inconclusive and no study has explored varietal differences in $\mathrm{CH}_{4}$ emissions of rice in Latin America. A field experiment was conducted in Colombia to investigate the potential of a breeding line, a commercial variety, and two rice hybrids to mitigate $\mathrm{CH}_{4}$ emissions from irrigated rice. Data on $\mathrm{CH}_{4}$ emissions, phenotypic, physiological, root traits, and grain yield were collected. Results showed $\mathrm{CH}_{4}$ emissions, grain yield, root length and root surface area differences followed the order Hybrid $2>$ Hybrid $1>$ breeding line $>$ Commercial variety. Whereas $\mathrm{CH}_{4}$ emissions per unit area for the two rice hybrids were within the of range $29-62 \%$ higher than the commercial variety and breeding line, $\mathrm{CH}_{4}$ emission per unit grain yield were similar across the rice genotypes. Our data suggests that differences in root development and grain yields explain genetic influence on $\mathrm{CH}_{4}$ emissions. We conclude that by exploiting differences in productivity and root characteristics among rice cultivars the transition towards low emission rice production systems can be accelerated.

\section{Introduction}

Rice (Oryza sativa L.) is a primary source of nutrients for over $50 \%$ of the world's inhabitants (GRiSP, 2013). In Latin America and the Caribbean (LAC), where per capita rice consumption is about $30 \mathrm{~kg}$ per year, most countries have rice deficits and require imports to cover their rice shortfalls (Durand-Morat and Bairagi, 2021; Maclean et al., 2002). However, the region is endowed with enormous terrestrial and water resources that can potentially support the expansion of the rice-growing area, particularly in Brazil, Colombia, and Venezuela (Espinosa, 2002). Currently, the area under irrigated rice represents between $73-74 \%$ of the overall rice cultivation area in the region (FLAR, 2021).

To produce rice in an environmentally benign manner, deliberate efforts are needed to reduce its contribution to total anthropogenic methane $\left(\mathrm{CH}_{4}\right)$ emissions without compromising yields (Islam et al., 2018). In irrigated rice systems, $\mathrm{CH}_{4}$ is produced by methanogenic bacteria, which dominate under anaerobic conditions that are prevalent in water-covered rice fields (Sass and Fisher, 1997). Subsequently, three pathways are responsible for $\mathrm{CH}_{4}$ transmission from the soil to the atmosphere: molecular diffusion, ebullition, and plant-mediated transport (Khosa et al., 2010). Previous studies have reported that $>90 \%$ of methane emitted from rice fields is lost through plant-mediated transport (HolzapfelPschorn et al., 1986; Butterbach-Bahl et al., 1997; Wassmann and Aulakh, 2000). Yet, despite the importance of plants in transmitting $\mathrm{CH}_{4}$ from the soil to the atmosphere, research on varietal differences in $\mathrm{CH}_{4}$ emissions is limited.

The focus of previous mitigation actions has targeted cultural practices such as fertilizer, crop residues, and irrigation management (Wassmann et al., 1993; Yagi et al., 1997; Wassmann et al., 2000), even 
though changing these aspects is challenging in the absence of supportive policies and economic incentives. Chirinda et al. (2018) suggested that taking advantage of varietal differences in $\mathrm{CH}_{4}$ emission is probably a more cost-effective approach for mitigating $\mathrm{CH}_{4}$ emission in $\mathrm{LAC}$ as the accompanying adjustment would not significantly alter farmer practices.

Various previous studies (e.g., Gogoi et al., 2008; Qin et al., 2015; Wang et al., 2017) suggest genotypic variations in $\mathrm{CH}_{4}$ emissions. In a study conducted in China comparing one rice variety to a rice hybrid, Zhang et al. (2019) reported that root morphology and physiological traits were negatively and significantly correlated with total $\mathrm{CH}_{4}$ emissions. Also, the rice hybrid used in the Chinese study had lower $\mathrm{CH}_{4}$ emissions and higher yields than the rice variety. This study hypothesized that rice hybrids would emit less $\mathrm{CH}_{4}$ emissions per unit yield due to having higher harvesting indexes than rice varieties. The possibility of rice genotypes that emit less $\mathrm{CH}_{4}$ without compromising yield represents an attractive approach for mitigating climate change while achieving food security goals (Balakrishnan et al., 2018). Therefore, monitoring $\mathrm{CH}_{4}$ emissions from different commercial varieties and hybrids is necessary to identify genotypes that reduce $\mathrm{CH}_{4}$ emissions without compromising grain yield. In addition, there is a need to understand the factors driving $\mathrm{CH}_{4}$ emission reductions to inform the focus of future breeding efforts.

\section{Materials And Methods}

\section{Experimental site and set-up}

The experiment was conducted at the experimental rice field at the International Center of Tropical Agriculture (CIAT), Cali, Colombia, from June to October 2019. The field was laid out in a randomized complete block design with four treatments in four replicates. The treatments were four rice cultivars comprising a commercial variety in Colombia, a CIAT experimental breeding line previously selected by its augmented root length, and two hybrids (Hybrid 1 and Hybrid 2) selected for their record of superior yield performance in field trials conducted at CIAT, as compared to check-inbred-varieties. Rice seedlings that were twenty-one days old were transplanted in the field plots on 17th June 2019. Soil properties at the experimental field are presented in Table 1 . The overall soil fertility is rated highly for rice production. Recommended irrigation rice management practices were conducted during the experimental period. All the plant materials used in this study come from a working germplasm collection conventionally bred by the International Center for Tropical Agriculture (CIAT) in Colombia. CIAT granted permission for the use of all the plant materials in this study. Seed sources used in this study are part of the working germplasm collection from the Rice Program at CIAT. 
Table 1

Soil properties at the study site.

\begin{tabular}{|lll|}
\hline Soil property & Unit & Value \\
\hline $\mathrm{pH}$ & - & 7.42 \\
\hline Nitrogen & $\mathrm{g} \mathrm{kg}^{-1}$ & 1.03 \\
\hline Available phosphorus & $\mathrm{mg} \mathrm{kg}^{-1}$ & 49.39 \\
\hline Cation exchange capacity & $\mathrm{cmol} \mathrm{kg}^{-1}$ & 37.1 \\
\hline Soil organic matter & $\mathrm{g} \mathrm{kg}^{-1}$ & 42.6 \\
\hline Calcium & $\mathrm{cmol} \mathrm{kg}^{-1}$ & 18.3 \\
\hline Magnesium & $\mathrm{cmol} \mathrm{kg}^{-1}$ & 9.5 \\
\hline Potassium & $\mathrm{cmol} \mathrm{kg}^{-1}$ & 0.7 \\
\hline Sodium & $\mathrm{cmol} \mathrm{kg}^{-1}$ & 0.6 \\
\hline Iron & $\mathrm{mg} \mathrm{kg}^{-1}$ & 14.0 \\
\hline Manganese & $\mathrm{mg} \mathrm{kg}^{-1}$ & 105.7 \\
\hline Copper & $\mathrm{mg} \mathrm{kg}^{-1}$ & 3.1 \\
\hline Zinc & $\mathrm{mg} \mathrm{kg}^{-1}$ & 21.9 \\
\hline Boron & $\mathrm{mg} \mathrm{kg}^{-1}$ & 0.5 \\
\hline Sulphur & $\mathrm{mg} \mathrm{kg}^{-1}$ & 44.5 \\
\hline Oxidized carbon & $\mathrm{g} \mathrm{kg}^{-1}$ & 18.75 \\
\hline 保 & & \\
\hline
\end{tabular}

\section{Land preparation and plot description}

The experimental site was ploughed, harrowed, and pulverized before transplanting mechanically. Then the fields were irrigated and puddled. Sixteen different plots $(5 \mathrm{~m} \times 4 \mathrm{~m})$ were then demarcated and used to host the different plant genotypes randomly. The gross plot size was $5 \mathrm{~m} \times 4 \mathrm{~m}\left(20 \mathrm{~m}^{2}\right)$, while the harvested net plot was $4 \mathrm{~m} \times 3 \mathrm{~m}\left(12 \mathrm{~m}^{2}\right)$.

\section{Fertiliser management}

The experimental plots were fertilized with nitrogen in the form of urea at $180 \mathrm{~kg} \mathrm{~N} \mathrm{ha}^{-1}$ and $200 \mathrm{~kg} \mathrm{~N}$ $\mathrm{ha}^{-1}$ for the varieties and hybrids, respectively. The nitrogen were applied in three split applications of 
$10 \%, 70 \%$ and $20 \%$ at 2,10 and 55 days after transplanting, respectively. Similar rates of phosphorus (65 $\mathrm{kg} \mathrm{ha}^{-1}$ ) and potassium ( $90 \mathrm{~kg} \mathrm{ha}^{-1}$ ) were applied in soils under the different varieties and hybrids.

\section{Plant measurements and analysis}

At least four times during the growing season, five aboveground plant samples were collected from each treatment plot (outside the harvest net plot). The plant samples were subsequently dried for $72 \mathrm{~h}$ at $60^{\circ} \mathrm{C}$. At harvest maturity dry weight of plants collected from different net plots $(4 \mathrm{~m} \times 3 \mathrm{~m})$ were partitioned between the leaves, stems, roots and panicles. Also, grain moisture content was determined at harvest maturity using agroTronix MT-PRO moisture metre. Following harvest, sub-samples of the harvested grain were used to characterize chalkiness using the method described by CIAT (1989). Root length, volume and surface area were determined using the method described by Ogawa et al. (2014). Briefly, at maturity, roots of five plants were harvested using a core sampler prior to washing and scanning using the EPSON scanner and analyzed using WinRhizo.

\section{Greenhouse gas sampling}

Gas measurements were conducted from the 10th of July to the 25th of September 2019. During the measurement campaign, gas sampling was initially aligned to fertilization, with measurements conducted one day before and three consecutive days after fertilization. After the fertilization period, measurements were conducted weekly until harvest. All samples were taken in the morning (8:00 to 11:00 a.m.). The method used for gas sampling was the static-closed chamber technique. Specifically, plastic buckets ( $114 \mathrm{~L}$ in volume and $80 \mathrm{~cm}$ height) were combined with custom-made chamber bases $(40 \mathrm{~cm}$ height) that included a canal, making it possible to have a water seal during chamber deployment. Vents were installed on each static chamber. A fan was also installed inside the chamber to mix air; therefore, each sample $(20 \mathrm{~mL})$, collected using a syringe and stored in a pre-evacuated vial, was representative of the air inside the chamber.

The methane concentration in the collected vials was analyzed by gas chromatography (Shimadzu GC2014). Methane fluxes were calculated using a gas concentration rate and sampling time (45 min) and the ideal gas equation. The cumulative fluxes for the monitoring period were calculated using linear interpolation and expressed in emissions per unit area (absolute emissions). $\mathrm{CH}_{4}$ emission intensities were calculated as a ratio of the cumulative emissions and the grain yield and expressed in $\mathrm{mg} \mathrm{CH}_{4}$ per $\mathrm{kg}$ of grain dry matter yield.

\section{Statistical Analyses}

The data were tested for normality. Since data on crop parameters were normally distributed, we analyzed it using the proc mixed procedure of SAS. The models used tested the responses of the different crop parameters to the genotype. The replicates were included as random effects. In connection with these models, pairwise comparisons were made using Differences of Least Square means. The methane data were non-normally distributed, and none of the transformation analyses obtained variance homogeneity 
and normal distribution. Therefore, we used a non-parametric method (the Wilcoxon Signed Rank test), which does not require an assumption of normality, to test the paired difference in methane emissions between the genotypes. While the adopted methods do not offer the breadth of statistical insights similar to parametric methods, the non-parametric methods are valuable when flux data are non-normal (Corre et al., 1996).

\section{Results}

\section{Aboveground biomass accumulation}

Figure 1 showed similar aboveground biomass accumulation in the hybrids, breeding line, and commercial variety at the active tillering and maximum tillering growth stages. However, at $50 \%$ flowering and physiological maturity, the two hybrids had significantly higher aboveground biomass than the breeding line and commercial variety.

\section{Root properties}

At physiological maturity, the root system was significantly longer in Hybrid 2 than other genotypes (Table 2). The root volume and surface area followed the same trend as root length, but values obtained in the breeding line (which was bred to develop longer roots) were similar to those in Hybrid 2 (which had the highest root volume) and higher than those obtained for Hybrid 1 and the commercial variety.

Table 2

Root parameters measured during the rice-growing season.

\begin{tabular}{|llll|}
\hline Genotype & $\begin{array}{l}\text { Root length at } \\
\text { physiological maturity } \\
(\mathbf{c m})\end{array}$ & $\begin{array}{l}\text { Root volume at } \\
\text { physiological maturity } \\
\left(\mathbf{c m}^{\mathbf{3}}\right)\end{array}$ & $\begin{array}{l}\text { Root surface area at } \\
\text { physiological maturity }\left(\mathbf{c m}^{2}\right)\end{array}$ \\
\hline $\begin{array}{l}\text { Commercial } \\
\text { variety }\end{array}$ & $2763^{\mathrm{a}}$ & $6.4^{\mathrm{a}}$ & $465^{\mathrm{a}}$ \\
\hline $\begin{array}{l}\text { Breeding } \\
\text { line }\end{array}$ & $3567^{\mathrm{a}}$ & $8.4^{\mathrm{ab}}$ & $607^{\mathrm{ab}}$ \\
\hline Hybrid 1 & $2908^{\mathrm{a}}$ & $8.1^{\mathrm{a}}$ & $540^{\mathrm{a}}$ \\
\hline Hybrid 2 & $3826^{\mathrm{b}}$ & $11.0^{\mathrm{b}}$ & $725^{\mathrm{b}}$ \\
\hline
\end{tabular}

\section{Grain yield}

Rice grain yields obtained were similar for the hybrids but significantly higher than those obtained for the breeding line and commercial variety (Table 3 ). The relative increase of hybrids' yield over the commercial variety was $26.4 \%$ and $26.7 \%$ for Hybrid 1 and Hybrid 2, respectively. When compared to the breeding line, Hybrid 1 and Hybrid 2 had $46.0 \%$ and $46.3 \%$ higher grain yield, respectively. 
Table 3

Cumulative greenhouse gas emissions, grain yield and grain quality parameters.

\begin{tabular}{|lllllll|}
\hline Genotype & $\begin{array}{l}\text { Cumulative } \\
\text { methane }(\mathbf{m g} \\
\left.\mathrm{CH}_{4} \mathbf{m}^{-2}\right)\end{array}$ & $\begin{array}{l}\text { Emission intentisty } \\
\left(\mathbf{m g ~ C H}_{4} \mathbf{k g}^{-1} \mathrm{dry}\right. \\
\text { matter) }\end{array}$ & $\begin{array}{l}\text { Grain } \\
\text { yield } \\
(\mathbf{k g} \\
\text { ha-1) }\end{array}$ & $\begin{array}{l}\text { Grains } \\
\text { per } \\
\text { panicle }\end{array}$ & $\begin{array}{l}1000 \\
\text { grain } \\
\text { weight } \\
(\mathbf{g})\end{array}$ & $\begin{array}{l}\text { Harvest } \\
\text { index } \\
(\%)\end{array}$ \\
\hline $\begin{array}{l}\text { Commercial } \\
\text { variety }\end{array}$ & $4338^{\mathrm{a}}$ & $0.73^{\mathrm{a}}$ & $6333^{\mathrm{a}}$ & $284^{\mathrm{a}}$ & $25.9^{\mathrm{a}}$ & 45.3 \\
\hline $\begin{array}{l}\text { Breeding } \\
\text { line }\end{array}$ & $4482^{\mathrm{a}}$ & $0.75^{\mathrm{a}}$ & $5801^{\mathrm{a}}$ & $376^{\mathrm{b}}$ & $26.2^{\mathrm{ab}}$ & 48.3 \\
\hline Hybrid 1 & $5761^{\mathrm{b}}$ & $0.65^{\mathrm{a}}$ & $8607^{\mathrm{b}}$ & $303^{\mathrm{ab}}$ & $24.2^{\mathrm{b}}$ & 43.0 \\
\hline Hybrid 2 & $7068^{\mathrm{c}}$ & $1.19^{\mathrm{a}}$ & $8647^{\mathrm{b}}$ & $397^{\mathrm{c}}$ & $23.9^{\mathrm{b}}$ & 52.0 \\
\hline
\end{tabular}

\section{Methane emissions}

Daily methane fluxes followed a similar trend in different genotypes (Fig. 2). However, the magnitude of cumulative methane emissions followed the order Hybrid $2>$ Hybrid $1>$ breeding line $>$ Commercial variety (Table 3). Hybrid 2 emitted 18.5\% higher than Hybrid 1, which emitted 22.2\% higher than the breeding line, and the breeding lines' methane emissions were $3.2 \%$ higher than those of the commercial variety. Despite differences in the magnitude of absolute $\mathrm{CH}_{4}$ emissions (i.e., emissions per unit area), being significantly higher in the hybrids than the breeding line and commercial variety, $\mathrm{CH}_{4}$ emission intensities (i.e., emissions per unit yield) were similar across genotypes.

\section{Discussion}

Based on the dominance of rice-mediated pathway of $\mathrm{CH}_{4}$ transmission from the submerged soil to the atmosphere (Jia and Cai, 2003), there is evidence that genetic variations of rice and their effects on plant parameters influence $\mathrm{CH}_{4}$ emissions from irrigated rice systems (Su et al., 2015; Qin et al., 2015; Baruah et al., 2010). The present study also demonstrated a significant difference between rice genotypes for methane emissions, with commercial variety and the breeding line emitting significantly less methane than the Hybrid genotypes.

Previous studies have reported that the difference between rice genotypes on methane emissions is mainly related to rice phenotypic and physiological parameters, i.e. the number of plant tillers, plant above and belowground biomass (Sinha 1995; Setyanto et al., 2004; Khosa et al., 2010). Other mechanisms that may influence observed genotypic variations in $\mathrm{CH}_{4}$ emissions include differences in (1) root exudates, which represent methanogenic substrate (Kerdchoechuen, 2005); (2) the development of aerenchyma (Aulakh et al. 2000); and (3) the size of methane-oxidizing sites in the rhizosphere (Win et al., 2012; Gutierrez et al., 2014). 
The roots of different rice genotypes may have other influences on the soil methanotrophic community composition (Lüke et al., 2011). Furthermore, some cultivars appear to allocate more of the products of photosynthesis to root exudation than others (Gutierrez et al., 2013; Su et al., 2015). Previous studies have reported that root exudates constitute an organic substrate for microbial organisms that could be utilized for methane production and oxidation by methanogens and methanotrophs, respectively (Win et al., 2012). Root exudates include simple sugars, which act as an electron donor under a flooded field, resulting in anaerobic conditions conducive to $\mathrm{CH}_{4}$ production (Wassman and Aulakh, 2000 and Le Mer and Roger, 2001).

To compare rice grain yield and methane emissions in irrigated rice systems, researchers have used yieldscaled emissions to indicate the global warming impact of rice production (Moiser et al., 2006; Pittelkow et al., 2013; Bayer et al., 2014). As suggested by Grassini and Cassman (2012), the yield-scaled metric is increasingly used to provide a measure of agronomic efficiency that begins to address both climate change and future food supply concerns. The present study aimed to identify rice genotypes with a high yield potential but lower methane emissions from among four rice genotypes. The results indicate that Hybrid 1 had high yield potential and moderate $\mathrm{CH}_{4}$ emissions resulting in low yield-scaled emissions. A higher rate of the partitioning of photosynthates to the developing panicles and grain accompanied by a higher rate of photosynthesis at the grain filling stage might be the reason for the higher grain yield in varieties with low methane emissions (Das and Baruah, 2008; Baruah et al., 2010). The partitioning of photosynthates to the panicles and grain will result in fewer carbohydrates being disposable for root exudates, an essential substrate for methanogens responsible for $\mathrm{CH}_{4}$ production (Su et al., 2015).

content

Previously a global range of seasonal $\mathrm{CH}_{4}$ emissions was reported to be between 2.7 to $1059 \mathrm{~kg} \mathrm{ha}^{-1}$ (Minami, 1995; Yan et al., 2009). The magnitude of $\mathrm{CH}_{4}$ emissions observed in this study ranged between 43.4-70.7 $\mathrm{kg} \mathrm{CH}_{4} \mathrm{ha}^{-1}$, well within the global range. Within the LAC region, using the commercial variety El Paso 144, a study conducted in Uruguay reported cumulative emissions ranging between 172.0 to $207.0 \mathrm{~kg} \mathrm{CH}_{4}$ ha $^{-1}$ (Irisarri et al., 2012). Another study conducted in Uruguay, using the same commercial variety El Paso 144, also reported higher cumulative emissions ranging from 208.0 to $249.0 \mathrm{~kg} \mathrm{CH}_{4} \mathrm{ha}^{-1}$ (Tarlera et al., 2016). In Colombia, a study conducted using the commercial variety FEDEARROZ-60 reported lower cumulative emissions of 7.5 and $19.5 \mathrm{~kg} \mathrm{CH}_{4}$ ha $^{-1}$ in 2015 and 2016, respectively (Chirinda et al., 2017). In Brazil, $\mathrm{CH}_{4}$ cumulative emissions observed for variety IRGA, 424 were 303.0$424.0 \mathrm{~kg} \mathrm{CH}_{4}$ ha $^{-1}$ (Zschornack et al., 2016) which was higher than those reported in the present study. The varietal differences may have contributed to the wide variation in the LAC region's methane emissions. The ideal rice cultivars for reducing methane emissions would probably need a high harvesting index, fewer ineffective tillers, panicles, and nodes (Wang et al., 1997). Additionally, the selection or breeding of rice genotypes that do not have well-developed aerenchyma systems may also mitigate $\mathrm{CH}_{4}$ emissions (Wassmann et al., 1993; Kludze et al., 1993). Focusing on rice cultivars for 
mitigating $\mathrm{CH}_{4}$ emissions is a more manageable approach, as it does not require farmers to change agronomic practices significantly (Balakrishnan et al., 2018).

\section{Perspectives}

While there is a need for further studies that explore $\mathrm{CH}_{4}$ emissions from more rice varieties and hybrids, our findings suggest a breeding solution for mitigating $\mathrm{CH}_{4}$ emissions from irrigated rice systems. Climate change mitigation-relevant breeding may need to focus on root systems - the interface between the plant (through which $\mathrm{CH}_{4}$ is transported to the atmosphere) and the soil (where the methane is formed). Specifically, our findings propose that breeding for shorter roots, lower root volume, and surface area without compromising yields may be beneficial in reducing rice-based methane emissions. On the other hand, to further incentivize the adoption of high-yielding and low $\mathrm{CH}_{4}$ emitting rice, such rice should be considered a clean development technology that could qualify for carbon credits. A low-yielding rice variety may result in low absolute emissions (per unit area). However, farmers will require more land to produce sufficient rice to reduce rice deficits in the region. Promoting hybrids could be a more promising approach for simultaneously achieving food security and emission goals.

\section{Declarations}

\section{Acknowledgement}

This research was supported by the CGIAR Research Program on Climate Change, Agriculture and Food Security (CCAFS) and the Global Research Alliance on Agricultural Greenhouse Gases (GRA) through their CLIFF-GRADS program. CCAFS is carried out with support from CGIAR Trust Fund and through bilateral funding agreements. For details, please visit https://ccafs.cgiar.org/donors. We are grateful to the International Center for Tropical Agriculture (CIAT), Palmira, Colombia, with in the rice program the physiology group and phenomics platform for their support different methodologies in physiology and root development and the Latin American Fund for Irrigated Rice (FLAR), Palmira, Colombia, for hosting the first author who was the recipient of the scholarship and to the Government of New Zealand for providing the financial support.

\section{Authors contributions}

N.C., E.G. and M.A. conceived the study. P.S., N.C., E.G., and M.A. experimented and collected the data. N.C. and P.S. analyzed the data. P.S., N.C., and M.A. wrote the manuscript. All authors reviewed the manuscript.

\section{Competing interests}

The authors declare that they have no competing interests.

\section{References}


1. Aulakh, M.S., Bodenbender, J., Wassmann, R., Rennenberg, H. (2000). Methane transport capacity of rice plants. II. Variations among different rice cultivars and relationship with morphological characteristics. Nutrient Cycling in Agroecosystems 58: 367-375.

2. Balakrishnan, D., Kulkarni, K., Latha, P.C., Subrahmanyam, D. (2018). Crop improvement strategies for mitigation of methane emissions from rice. Emirates Journal of Food and Agriculture 30: 451-462.

3. Baruah, K.K., Gogoi, B., Gogoi, P (2010). Plant physiological and soil characteristics associated with methane and nitrous oxide emission from rice paddy. Physiology and Molecular Biology of Plants, 16, 79-91. https://doi.org/10.1007/s12298-010-0010-1

4. Bayer, C., Souza Costa, F-S., Pedroso, G.M., Zschornack, T., Camargo, E.S., de Lima, M.A., Frigheto, R.T.S., Gomes, J., Marcolin, E., Macedo, V.R.M. (2014). Yield-scaled greenhouse gas emissions from flood irrigated rice under long-term conventional tillage and no-till systems in a Humid Subtropical climate. Field Crops Research, 162, 60-69.

5. Butterbach-Bahl, K., Papen, H., Rennenberg, H. (1997). Impact of gas transport through rice cultivars on methane emission from paddy fields. Plant Cell Environ 20:1175-1183

6. Centro Internacional de Agricultura Tropical (CIAT). (1989). Evaluación de la calidad culinaria y molinera del arroz; guía de estudio para ser usada como complemento de la unidad audio tutorial sobre el mismo tema. Contenido científico: César Martinez, Federico Cuevas. Producción: Luz Medina. Cali, Colombia. CIAT 73 p. (Serie 04SR-07.01). Pag 27-42.

7. Chirinda, N., Arenas, L., Katto, M., Loaiza, S., Correa, F., et al (2018). Sustainable and Low Greenhouse Gas Emitting Rice Production in Latin America and the Caribbean: A Review on the Transition from Ideality to Reality. Sustainability, 10, 671; doi:10.3390/su1003067.

8. Chirinda, N., Arenas, L., Loaiza, S., et al (2017). Novel technological and management options for accelerating transformational changes in rice and livestock systems. Sustainability, 9, 1891; doi:10.3390/su9111891.

9. Corre, M. D., van Kessel, C., Pennock, D. J. (1996). Landscape and seasonal patterns of nitrous oxide emissions in a semiarid region Soil Sci. Soc. Am. J. 60, 1806-1816

10. Das, K., Baruah, K. K. (2008). Methane Emission Associated with Anatomical and Morphological Characteristics of Rice (Oryza sativa) Plant. Physiologia Plantarum, 134,303312.https://doi.org/10.1111/j.1399-3054.2008.01137.x

11. Durand-Morat, A., Bairagi, S. (2021). AGREP Global Rice Market Outlook, 2020-2030. The Arkansas Global Rice Economics Program (AGREP), University of Arkansas, Fayetteville, AR.

12. Espinosa, J. (2002). Rice Nutrition Management in Latin America. Better Crops Int., 16, 36-39.

13. FLAR (2021). Monitoring and Follow-up Survey of the Rice Sector in Latin America - EMSAL. Latin American Fund for Irrigated Rice.

14. Gogoi, N., Baruah, K. K., Gupta, P. K. (2008). Selection of rice genotypes for lower methane emission. Agron. Sustain. Dev. 28: 181-186.

15. Grassini, P., Cassman, K. (2012). High-yield maize with large net energy yield and small global warming intensity. Proceedings of the National Academy of Sciences of the United States of 
America, 109, 1074-1079. https://doi.org/10.1073/pnas.1116364109

16. GRiSP (Global Rice Science Partnership). (2013). 2013 Rice Almanac, 4th ed.; International Rice Research Institute: Los Baños, Philippines; p. 283.

17. Gutierrez, J., Atulba, S.L., Kim, G., Kim, P.J. (2014). Importance of rice root oxidation potential as a regulator of $\mathrm{CH}_{4}$ production under waterlogged conditions. Biology and Fertility of Soils 50, 861868.

18. Gutierrez, J., Kim, S.Y., Kim, P.J., (2013). Effect of rice cultivar on CH4 emissions and productivity in Korean paddy soil. Field Crops Research, 146, 16-24.

19. Holzapfel-Pschorn, A., Conrad, R. and Seiler, W. (1986). Effects of vegetation on the emission of methane from submerged paddy soil. Plant Soil 92:223-391

20. Irisarri, P., Pereyra, V., Fernández, A., Terra, J., Tarlera, S. (2012). Emisiones de $\mathrm{CH}_{4}$ y $\mathrm{N}_{2} \mathrm{O}$ en un arrozal: primeras medidas en el sistema productivo uruguayo. Agrociencia (Uruguay), 16(2), 1-10. Recuperado en 11 de enero de 2022, de http://www.scielo.edu.uy/scielo.php? script=sci_arttext\&pid=S2301-15482012000200001\&lng=es\&tlng=pt.

21. Islam S. F., Groenigen, J. W. V., Lars Stoumann Jensen, L. S., Bjoern Ole Sander, B. O., de Neergaard, A. (2018). The effective mitigation of greenhouse gas emissions from rice paddies without compromising yield by early-season drainage. Science of the Total Environment 612:1329-1339. http://dx.doi.org/10.1016/j.scitotenv.2017.09.022

22. Jia Z and Cai Z (2003). Effects of rice plants on methane emission from paddy fields. The Journal of Applied Ecology 14:2049-2053.

23. Kerdchoechuen, O. (2005). Methane emission in four rice varieties as related to sugars and organic acids of roots and root exudates and biomass yield. Agriculture Ecosystems Environment 108, 155163.

24. Khosa, M.K., Sidhu, B.S., Benbi, D.K. (2010). Effect of organic materials and rice cultivars on methane emission from rice field. Journal of Environmental Biology 31: 281-285

25. Kludze, H.K., DeLaune, R.D., Patrick, W.H. (1993). Aerenchyma formation and methane and oxygen exchange in rice. Soil Science Society of America Journal 57: 386-391.

26. Le Mer, J., Roger, P. (2001). Production, oxidation, emission and consumption of methane by soils: a review. Eur. J. Soil Biol. 37, 25-50

27. Lüke, C., Bodrossy, L., Lupotto, E., Frenzel, P. (2011). Methanotrophic bacteria associated to rice roots: the cultivar effect assessed by T-RFLP and microarray analysis. Environmental Microbiology Reports $3,518-525$.

28. Maclean, J.L., Dawe, D.C., Hardy, B., Hettel, G.P (eds) (2002), Rice Almanac: Sourcebook for the most important economic activity on earth. International Rice Research Institute, CABI Publishing.

29. Minami, K., 1995. The effect of nitrogen fertilizer use and other practices on methane emission from flooded rice. Fertil. Res. 40, 71-84. 
30. Moiser, A.R., Halvorson, A.D., Reulle, C.A., Liu, X.J. (2006). Net global warming potential and greenhouse gas intensity in irrigated cropping systems in Northern Colorado. Journal of Environmental Quality 35, 1584-1598.

31. Ogawa, S., Selvaraj, M.G., Fernando, A.J. et al. (2014). N- and P-mediated seminal root elongation response in rice seedlings. Plant Soil 375, 303-315. https://doi.org/10.1007/s11104-013-1955-y

32. Pittelkow, C.M., Adviento-Borbe, M.A., Hill, J. E., Six, J., van Kessel, C., Linquist, B. A., (2013). Yieldscaled global warming potential of annual nitrous oxide and methane emissions from continuously flooded rice in response to nitrogen input. Agriculture, Ecosystems \& Environment 177, 10-20.

33. Qin, X., Y. Li, H. Wang, J. Li, Y. Wan, Q. Gao, Y. Liao and M. Fan. 2015. Effect of rice cultivars on yieldscaled methane emissions in a double rice field in South China. J Integr. Environ. Sci. 12 Suppl. 1: 47-66

34. Sass, R.L., Fisher (Jr). F.M. (1997). Methane emissions from rice paddies: a process study summary. Nutrient Cycling in Agroecosystems 49:119-127.

35. Setyanto, P., Rosenani, A.B., Boer, R., Fauziah, C.I., Khanif, M.J. (2004) The effect of rice cultivars on methane emission from irrigated rice field. Indonesian Journal of Agricultural Science 5, 20-31.

36. Sinha S.K. (1995). Global methane emission from rice paddies: Excellent methodology but poor extrapolation, Current Science 68, 643-646

37. Su, J., Hu, C., Yan, X., Jin, Y., Chen, Z., Guan, Q., Wang, Y., Zhong, D., Jansson, C., Wang, F., Schnürer, A., Sun, C. (2015). Expression of barley SUSIBA2 transcription factor yields high-starch low-methane rice. Nature 30; 523(7562):602-6. doi: 10.1038/nature14673.

38. Tarlera, S., Capurro, M. C., Irisarri, P., Scavino, A. F., Cantou, G., \& Roel, A. (2016). Yield-scaled global warming potential of two irrigation management systems in a highly productive rice system. Scientia Agricola. https://doi.org/10.1590/0103-9016-2015-0050

39. Wang, B., Neue, H. U., Samonte, H. P. (1997). Role of rice in mediating methane emission. Plant Soil 189:107-115

40. Wang, C., Lai, D. Y. F., Sardans, J., Wang, W., Zeng, C., Peñuelas, J. (2017). Factors Related with $\mathrm{CH}_{4}$ and $\mathrm{N}_{2} \mathrm{O}$ Emissions from a Paddy Field: Clues for Management implications. PLoS ONE 12: e0169254. doi:10.1371/journal.pone.0169254

41. Wassmann, R., Aulakh, M.S. (2000). The role of rice plants in regulating mechanisms of methane emissions. Biol. Fertil. Soils 31, 20-29.

42. Wassmann, R., Lantin, R. S., Neue, H. U., Buendia, L. V., Corton, T. M., Lu, Y. (2000) Characterization of methane emissions from rice fields in Asia. III. Mitigation options and future research needs. Nutr. Cycl. Agroecosyst. 58, 23-36. doi:10.1023/A:1009874014903

43. Wassmann, R., Papen, H., Rennenberg, H. (1993). Methane emission from rice paddies and possible mitigation strategies. Chemosphere, 26(1-4), 201-217. https://doi.org/10.1016/00456535(93)90422-2 
44. Win, K.T., Nonaka, R., Win, A.T., Sasada, Y., Toyota, K., Motobayashi, T., Hosomi, M., (2012). Comparison of methanotrophic bacteria, methane oxidation activity, and methane emission in rice fields fertilized with anaerobically digested slurry between a fodder rice and a normal rice variety. Paddy Water Environment 10, 281-289.

45. Yagi, K., Tsuruta, H., Minami, K., 1997. Possible options for mitigating methane emission from rice cultivation. Nutrient Cycling in Agroecosystems 49, 213-220.

46. Yan, X., Akiyama, H., Yagi, K., Akimoto, H., 2009. Global estimations of the inventory and mitigation potential of methane emissions from rice cultivation conducted using the 2006 Intergovernmental Panel on Climate Change Guidelines. Glob. Biogeochem. Cycles 23 (2), GB2002.

47. Zhang, H., Liu, H., Hou, D., Zhou, Y., Liu, M., Wang, Z., Liu, L., Gu, J., Yang, J. (2019). The effect of integrative crop management on root growth and methane emission of paddy rice. The Crop Journal, 7: 444-457

48. Zschornack, T., da Rosa, C. M., Pedroso, G. M., Marcolin, E., da Silva, P. R. F., \& Bayer, C. (2016). Mitigation of yield-scaled greenhouse gas emissions in subtropical paddy rice under alternative irrigation systems. Nutrient Cycling in Agroecosystems. https://doi.org/10.1007/s10705-016-9775-0

\section{Figures}




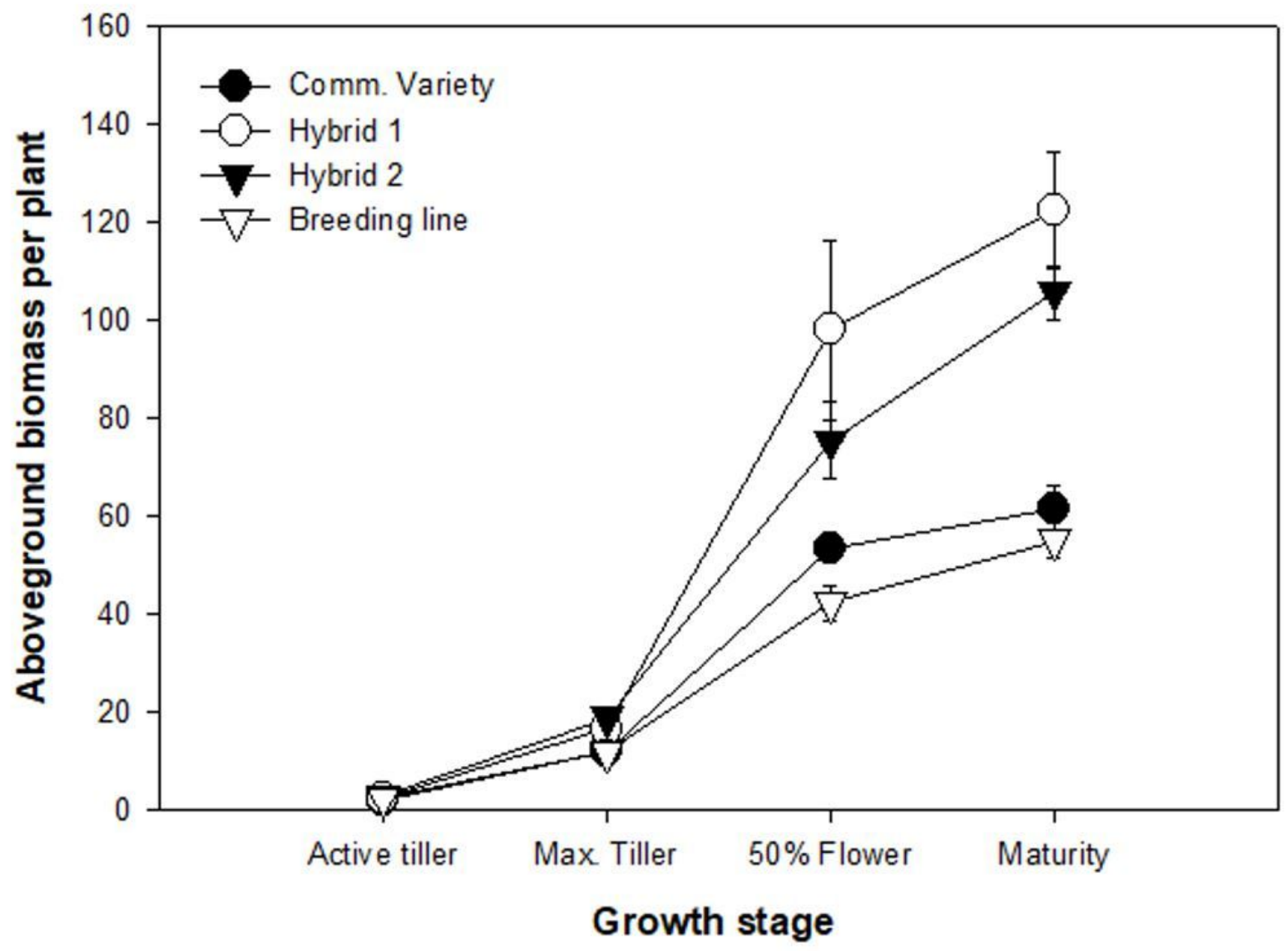

Figure 1

Aboveground biomass accumulation by the four rice cultivars at four growth stages (active tillering, maximum tillering, $50 \%$ flowering and maturity). 


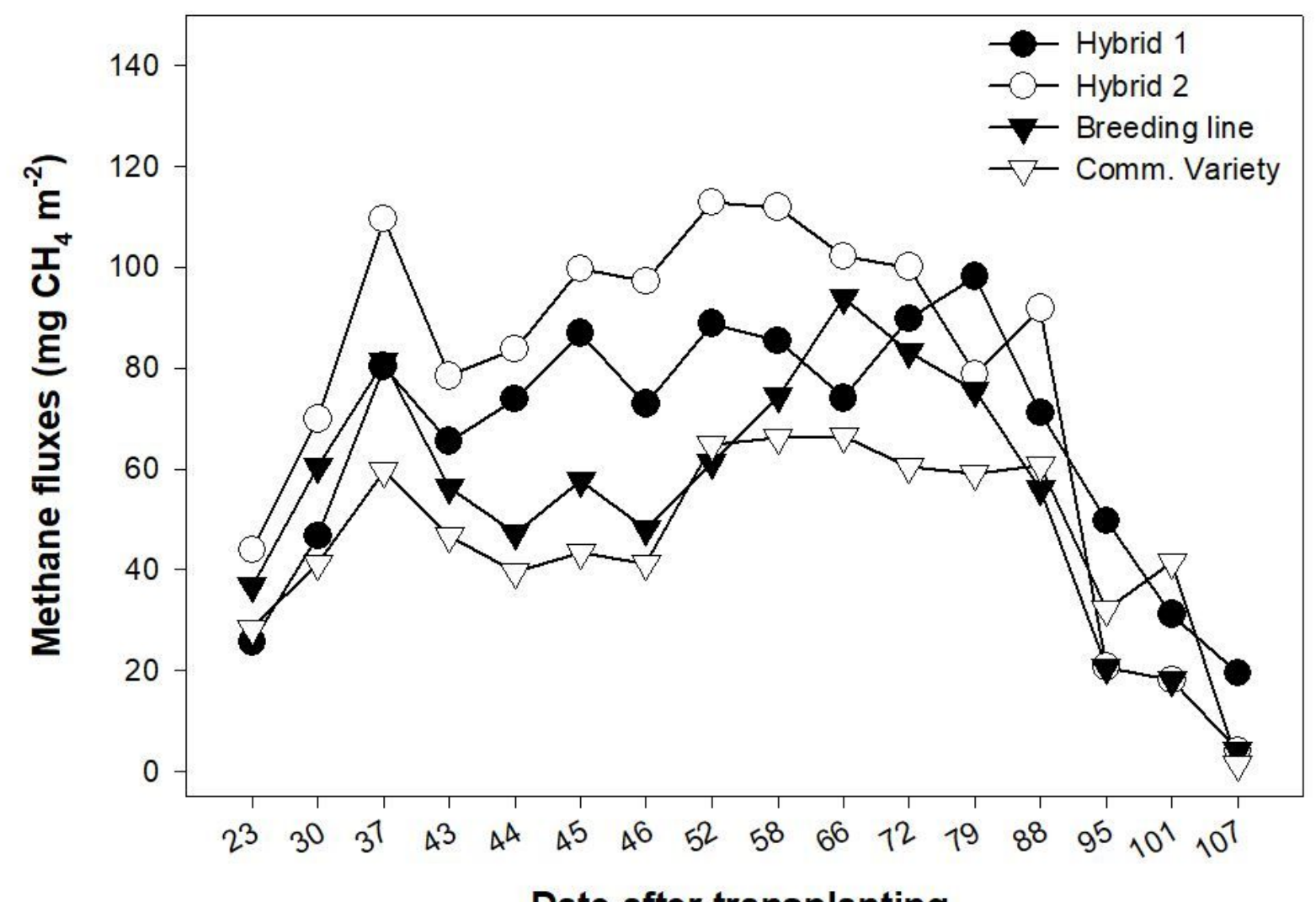

Date after transplanting

Figure 2

Methane emission dynamics of four rice cultivars as affected by days after transplanting.

\section{Supplementary Files}

This is a list of supplementary files associated with this preprint. Click to download.

- Supplementaryinformation.docx 